\title{
PENGARUH pH, DAN LAMA FERMENTASI TERHADAP PRODUKSI ETHANOL DARI Sargassum crassifolium
}

\author{
Mulyadi Taslim ${ }^{1}$, Meggy Mailoa ${ }^{2}$, Muhammad Rijal $^{3}$ \\ ${ }^{1}$ Laboratorium MIPA, Institut Agama Islam Negeri Ambon \\ ${ }^{2}$ Pascasarjana Ilmu Perikanan dan Kelautan Unpatti Ambon \\ ${ }^{3}$ Jurusan Pendidikan Biologi, IAIN Ambon \\ E-mal: mulyadi_taslim@gmail.com
}

\begin{abstract}
Abstrak: Sargassum banyak mengandung polisakarida alginat yang dimanfaatkan untuk industri makanan-minuman, kosmetik, dan farmasi. Selain itu mengandung jenis polisakarida lain yaitu selulosa (bagian dari dinding sel), manithol (sebagai karbohidrat tersimpan) dan fucoidan. Kandungan selulosa pada Sargassum berkisar antara 23,97$35,22 \%$ sehingga dapat diolah menjadi bahan dasar dalam pembuatan bioethanol. Hasil penelitian menunjukkan bahwa $\mathrm{pH}$ medium 7 dan lama fermentasi 72 jam memberikan hasil yang terbaik dalam meningkatkan produksi dan kadar bioethanol berbahan dasar Sargassum crasifolium
\end{abstract}

Kata Kunci: Ph, Lama Fermentasi, Bioethanol, Sargassum Crasifolium

\section{THE INFLUENCE OF pH, AND LONG FERMENTATION TO ETHANOL PRODUCTION OF Sargassum crassifolium}

\begin{abstract}
Sargassum do contain many a polysaccharide alginat that is occupied for makanan-minuman making is a sunset industry, cosmetics, and pharmacy. In addition there is a containing a kind of a polysaccharide he raised some of cellulose (part of a cell wall), manithol (as carbohydrates record of the wicked) and fucoidan. The moisture content of cellulose on sargassum in size ranges from $23,97-35,22 \%$ so that it can be processed into a basic source of some in the manufacture of bioethanol. The research results show that carried out medium a $\mathrm{pH}$ of 7 and long fermentation 72 hours pay the price of their the best in promoting business production and the nature of all that bioethanol as a raw material outside Sargassum crasifolium
\end{abstract}

\section{Kata Kunci: pH, Long Fermentation, Bioethanol, Sargassum Crasifolium}

Secara umum kebutuhan energi di dunia sampai saat ini masih bergantung pada sumber daya fosil terutama minyak dan gas bumi serta batu bara. Sumber daya alam tersebut telah terbentuk ribuan tahun lalu. Tingkat konsumsi manusia terhadap energi fosil lebih tinggi 
dibandingkan dengan laju pembentukannya. Padahal sumber daya energi tersebut termasuk sumber daya yang tak terbarukan (non renewables) yang berarti bila dilakukan pengambilan terus menerus maka pada suatu saat ketersediaannya di alam akan habis. Apabila penggunaan bahan bakar terus dieksploitasi maka dikhawatirkan akan terjadi krisis bahan bakar yang berdampak keras terhadap kualitas hidup masyarakat seperti yang kita rasakan saat ini (Pusdatin, 2012). Usaha pengembangan dan pemanfaatan sumber energi baru dan terbarukan sangat tergantung kepada masalah kelayakan ekonomi. Permasalahan ini akan lebih tampak bila usaha penerapannya dikembangkan di negaranegara yang sedang berkembang. Namun penerapan teknologi tertentu masih belum layak secara ekonomi apabila diterapkan untuk wilayah pedesaan. Oleh karena itu perlu dipikirkan pengembangan teknologinya yang tepat guna agar tingkat adaptasinya dapat lebih tinggi bagi keadaan pedesaan dan pertanian di Indonesia (Mangunwidjaja, 2005).

Sudah saatnya penggunaan sumber energi terbarukan berupa bahan bakar nabati (BNN) atau bioenergi ditingkatkan, menggantikan bahan bakar fosil yang semakin berkurang. Salah satu contoh bahan bakar nabati cair yaitu pengganti bensin yang bernama bioetanol. Bioetanol adalah cairan yang dihasilkan dari proses fermentasi bahan nabati yang mengandung komponen kimia dari golongan karbohidrat yaitu berupa pati, amilum, serat, selulosa dan lainya oleh mikroorganisme seperti kapang, khamir ataupun bakteri melalui proses konversi komponen kimia tersebut menjadi glukosa yang kemudian didestilasi menjadi cairan kimia yang disebut etanol (Khaidir dkk, 2012). Etanol merupakan senyawa organik yang terdiri dari karbon, hidrogen dan oksigen sehingga dapat dilihat sebagai turunan senyawa hidrokarbon yang mempunyai gugus hidroksil dengan rumus kimia $\mathrm{C}_{2} \mathrm{H}_{5} \mathrm{OH}$. Etanol atau etil alkohol dikenal dengan alkohol adalah zat cair, tak berwarna, berbau spesifik, mudah terbakar dan menguap, dapat bercampur dalam air dengan segala perbandingan dan memiliki sifat menyerupai premium (Khairani, 2007).

Bioetanol dapat dihasilkan dari bahan-bahan nabati dan pemanfataan bahan-bahan hayati tersebut telah banyak diteliti dan dikembangkan dalam memproduksi bioetanol seperti: singkong, jagung, sagu, aren, tebu dan biji-bijian yang pada dasarnya mengandung molekul karbohidrat yang dapat dikonversi menjadi bioetanol. Hal lain yang paling unik dan menarik dari pembuatan bioetanol pun kini marak diteliti dan dibuat dengan memanfaatkan limbah organik yang tidak terpakai lagi seperti kulit pisang, ampas tebu, ampas sagu, kulit ubi dan juga tongkol jagung serta limbah organik lainnya. Bukan hanya itu saja, bahkan sekarang ini organisme laut pun mendapat sorotan tajam oleh peneliti dengan memanfaatkan rumput laut (Alga) sebagai bahan baku pembuatan bioetanol salah satunya yaitu alga cokelat dari spesies Sargassum. 


\section{METODE PENELITIAN}

Jenis penelitian ini adalah penelitian kuantitatif eksperimen laboratorium (laboratorium eksperiment), yang bertujuan untuk mengetahui pengaruh $\mathrm{pH}$ media dan lama fermentasi terhadap produksi dan kadar bioethanol dari S. crasifolium. Variabel terikat yang diukur adalah produksi bioethanol dalam satuan $(\mathrm{ml})$. Perlakuan dalam penelitian ini adalah: $\mathrm{pH}$ Medium $\left(\mathrm{B}_{1}=\mathrm{PH} 5 ; \mathrm{B}_{2}=\mathrm{PH} 6 ; \mathrm{B}_{3}=\mathrm{PH} 9\right)$ dan Lama Fermentasi $\left(\mathrm{C}_{1}=\right.$ Lama Fermentasi $=24$ jam; $\mathrm{C}_{2}=$ Lama Fermentasi $=48$ jam; dan $\mathrm{C}_{3}=$ Lama Fermentasi 72 jam).

Penelitian ini dilaksanakan pada bulan Mei - Agustus 2017. Tempat pengambilan sampel S. crassifolium yaitu di Desa Liang, Kecamatan Salahutu, Kabupaten Maluku Tengah; tempat melakukan preparasi sampel dilakukan di Laboratorium MIPA Institut Agama Islam Negeri Ambon untuk reparasi sampel; tempat melakukan proses destilasi hasil fermentasi dilakukan di Laboratorium Kimia Fakultas Keguruan dan Ilmu Pendidikan Unpatti; dan analisis kadar etanol bertempat di Laboratorium Kimia Universitas Muhammadiyah Malang. Adapun prosedur penelitian ini meliputi:

\section{Persiapan Subtrat Fermentasi}

\section{a. Persiapan sampel Sargassum crassifolium}

Sargassum crassifolium yang digunakan berasal dari perairan laut desa Liang. Persiapan sampel $S$. crassifolium dilakukan dengan cara mengambil S. crassifolium sebanyak yang dibutuhkan dengan menggunakan gunting, kemudian sampel dicuci dengan air tawar, setelah itu keringkan dengan bantuan sinar matahari selama 12 jam. $S$. crassifolium yang sudah kering dipotong-potong dengan ukuran $1 \mathrm{~cm}$ kemudian diblender. Tahapan selanjutnya yaitu mengoven sampel $S$. crassifolium yang telah digiling pada suhu $50^{\circ} \mathrm{C}$ selama 4 jam (Aryani, dkk. 2013).

\section{b. Delignifikasi}

Delignifikasi dilakukan dengan menimbang sebanyak 100 gram serbuk $S$. crassifolium ditambah dengan $500 \mathrm{ml} \mathrm{NaOH} 2 \%$ ke dalam Erlenmeyer kemudian dipanaskan dan diaduk dengan stirrer selama 3 jam pada suhu $80^{\circ} \mathrm{C}$. Selanjutnya larutan dipisahkan dengan cara disaring. Serbuk S. crassifolium yang telah terpisah dibilas dengan air (Richana, 2011).

\section{c. Hidrolisis}

Proses hidrolisis dilakukan dengan cara, filtrat hasil delignifikasi yang telah dimasukkan kedalam Erlenmeyer dengan menambahkan larutan $\mathrm{HCl} 21 \%$ sebanyak 500 ml, kemudian larutan hidrolisis dimasukkan kedalam oven dengan suhu $80^{\circ} \mathrm{C}$ selama 3 jam (Richana, 2011).

\section{d. Persiapan starter}

Starter yang digunakan adalah ragi roti yang ditumbuhkan dalam subtrat pertumbuhan. Ragi yang digunakan dalam penelitian ini, yaitu ragi komersil yang dijual dipasaran dengan merek pakmaya. Substrat pertumbuhan terdiri dari $1000 \mathrm{ml}$ aquades 
yang ditambahkan dengan 100g gula pasir (konsentrasi 10\%) yang disiapkan di dalam gelas beaker. Setelah semua bahan-bahan dimasukkan, kemudian dihomogenkan terlebih dengan magnetic stirrer kemudian disterilkan dengan menggunakan autoclave pada suhu $121{ }^{\circ} \mathrm{C}$ selama 15 menit. Substrat ditunggu hingga dingin. Setelah dingin, sampai kirakira mencapai suhu $30-33{ }^{\circ} \mathrm{C}$, ragi dimasukan ke dalam subtrat, selanjutnya diinkubasi kedalam incubator pada suhu $30^{\circ} \mathrm{C}$ selama 8 jam (Azizah. dkk, 2012). Banyak ragi pada pembuatan starter adalah $3 \%$.

\section{e. Inokulasi starter}

Setelah starter diinkubasi selama 8 jam, maka starter tersebut siap untuk diinokulasikan di dalam subtrat fermentasi. Starter dimasukan dalam medium fermentasi pada kondisi yang aseptis. Jumlah starter yang dimasukkan adalah sebanyak 10\% (Richana, 2011).

\section{Fermentasi}

Proses fermentasi dilakukan dengan menyaring filtrat dari proses hidrolisis, kemudian hasil saringan berupa cairan dimasukkan kedalam erlenmeyer dan ditambahkan $\mathrm{NaOH}$ atau $\mathrm{HCl}$ sampai pH menjadi 5, 6 dan 7 untuk variasi pH (Ariyani. dkk, 2012), lalu menambahkan starter sebanyak $300 \mathrm{ml}$ sesuai konsentrasi starter. Proses fermentasi dilakukan sesuai dengan waktu perlakuan, yaitu mulai dari 48 jam, 72 jam, dan 96 jam (Azizah. dkk, 2012).

\section{Destilasi}

Pengujian kadar alkohol diawali dengan proses destilasi. Hasil fermentasi didestilasi untuk memisahkan etanol dengan larutan lainnya. Destilasi dilakukan pada suhu $80^{\circ} \mathrm{C}$ (Ariyani. dkk, 2012).

\section{Pengujian Kadar Etanol}

Pengujian kadar etanol dilakukan dengan metode Chromatography Gas (GC). Hasil dari metode Chromatography Gas (GC) ini yaitu berupa kromatogram, dimana dari kromatogram tersebut dapat diketahui: Waktu retensi, \% luas area, dan \% tinggi atau kadar. Analisis dengan GC dilakukan dengan menginjeksi $1 \mu \mathrm{L}$ sampel. Kemudian profil kromatograf sampel dibandingkan dengan references standard pada program GC-MS dengan menekan similary search (Fitriana, 2009).

\section{HASIL PENELITIAN}

Pemanfataan bahan-bahan hayati telah banyak diteliti dan dikembangkan dalam memproduksi bioetanol seperti singkong, jagung, sagu, aren, tebu dan biji-bijian yang pada dasarnya mengandung molekul karbohidrat yang dapat dikonversi menjadi bioetanol. Hal lain yang paling unik dan menarik dari pembuatan bioetanol pun kini marak diteliti dan dibuat dengan memanfaatkan limbah organik yang tidak terpakai lagi seperti kulit pisang, ampas tebu, ampas sagu, kulit ubi dan juga tongkol jagung serta limbah organik lainnya. Bukan hanya itu saja, bahkan sekarang ini organisme laut pun 
mendapat sorotan tajam oleh peneliti dengan memanfaatkan rumput laut sebagai bahan baku pembuatan bioetanol salah satunya yaitu alga cokelat dari spesies Sargassum crassifolium

Sargassum crassifolium merupakan salah satu jenis alga cokelat yang kaya akan manfaat serta memiliki nilai ekonomis tinggi, memiliki umur panen yang relatif singkat, tersebar luas di perairan laut Indonesia dengan potensi produksinya cukup tinggi namun produksinya masih banyak berasal dari hasil panen persediaan dari alami. S. crassifolium banyak mengandung polisakarida alginat yang dimanfaatkan untuk industri makananminuman, kosmetik, dan farmasi. Polisakarida lainnya adalah selulosa (bagian dari dinding sel), manithol (sebagai karbohidrat tersimpan) dan fucoidan. Selulosa pada Sargassum berkisar antara 23,97-35,22\%. Selulosa yang dimanfaatkan adalah produk turunannya yaitu carboxymethyl cellulose (cmc) yang banyak dimanfaatkan sebagai bahan penstabil, pengental, dan pengemulsi. Kandungan selulosa yang tinggi pada sargassum merupakan salah satu potensi untuk dijadikan sebagai bahan dalam memproduksi bioethanol (Kadi \& Atmadja, 1996). Penggunaa variasi $\mathrm{pH}$ media dengan penggunaan konsentrasi ragi $1 \%$ dan lama fermentasi 24 jam dengan hasil sebagai berikut Tabel 1. Pengaruh pH Media Terhadap Produksi (ml) dan Kadar Bioethanol (\%)

\begin{tabular}{|c|c|c|}
\hline $\mathrm{pH}$ Media & Produksi Bioetanol (ml) & Kadar Bioetanol (\%) \\
\hline 5 & 46 & 8.643 \\
\hline 6 & 53 & 9.168 \\
\hline 7 & 70 & 9.943 \\
\hline
\end{tabular}

Berdasarkan Tabel 1 tersebut diketahui bahwa produksi dan kadar bioetanol untuk $100 \mathrm{~g}$ berat kering $S$. crassifolium yang dihasilkan dari masing-masing perlakuan dengan penggunaan konsentrasi ragi dan lama fermentasi yang tetap adalah berbeda, dengan volume dan kadar terendah diperoleh pada perlakuan $\mathrm{pH}$ 5, sedangkan volume dan kadar bioethanol tertinggi diperoleh pada perlakuan $\mathrm{pH}$ 7. Data tentang perbandingan volume dan kadar bioethanol dari masing-masing perlakuan dapat dilihat pada Gambar 1 berikut 


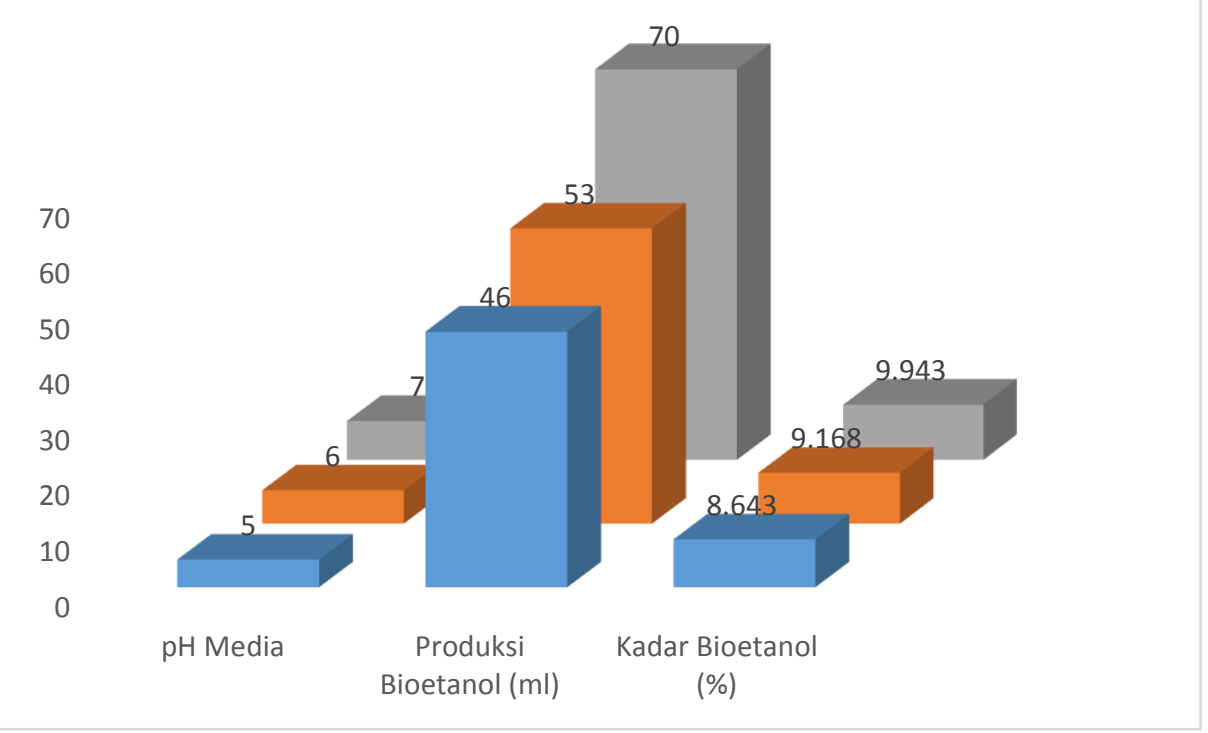

Gambar 1. Hubungan pH Media dengan Produksi (ml) dan Kadar Bioethanol (\%)

Berdasarkan Gambar 1 tersebut, terlihat bahwa volume dan kadar bioethanol pada tiap-tiap perlakuan berbeda. Volume dan konsentrasi bioethanol pada perlakuan $\mathrm{pH}=5$ adalah $46 \mathrm{ml}$ dan $8.643 \%$; volume dan konsentrasi bioethanol pada perlakuan $\mathrm{pH}=4$ adalah $53 \mathrm{ml}$ dan $9.168 \%$; dan volume serta konsentrasi bioethanol pada perlakuan $\mathrm{pH}=$ 7 adalah $70 \mathrm{ml}$ dan $9.943 \%$. Selain perlakuan $\mathrm{pH}$ media, dalam penelitian ini juga digunakan variasi lama fermentasi dengan penggunaan konsentrasi ragi dan $\mathrm{pH}$ media tetap dengan hasil sebagai berikut

Tabel 2. Pengaruh Lama Fermentasi Terhadap Produksi (ml) dan Kadar Bioethanol (\%)

\begin{tabular}{|c|c|c|}
\hline $\begin{array}{c}\text { Lama Fermentasi } \\
(\text { Jam })\end{array}$ & Produksi Bioetanol (ml) & Kadar Bioetanol (\%) \\
\hline 24 & 46 & 8.643 \\
\hline 48 & 56 & 11.081 \\
\hline 72 & 67 & 14.043 \\
\hline
\end{tabular}

Berdasarkan Tabel 2 tersebut diketahui bahwa produksi dan kadar bioetanol untuk $100 \mathrm{~g}$ berat kering $S$. crassifolium yang dihasilkan dari masing-masing perlakuan dengan penggunaan konsentrasi ragi dan $\mathrm{pH}$ media yang tetap adalah berbeda, dengan volume dan kadar terendah diperoleh pada perlakuan lama fermentasi 24 jam, sedangkan volume dan kadar bioethanol tertinggi diperoleh pada perlakuan lama fermentasi 72 jam. Data tentang perbandingan volume dan kadar bioethanol dari masing-masing perlakuan dapat dilihat pada Gambar 2 berikut 


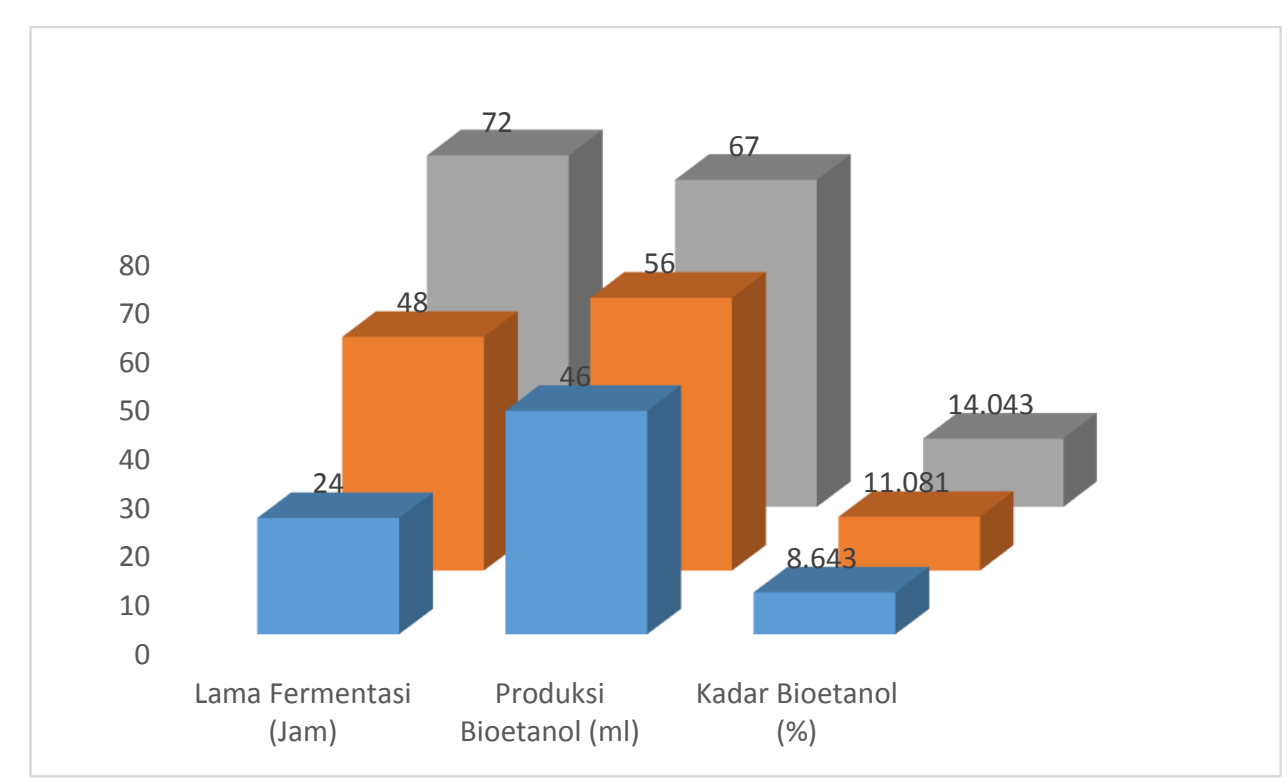

Gambar 2. Hubungan Lama Fermentasi (Jam) dengan Produksi (ml) dan Kadar Bioethanol (\%)

Berdasarkan Gambar 2 tersebut, terlihat bahwa volume dan kadar bioethanol pada tiap-tiap perlakuan berbeda. Volume dan konsentrasi bioethanol pada perlakuan lama fermentasi $=24$ jama adalah $46 \mathrm{ml}$ dan $8.643 \%$; volume dan konsentrasi bioethanol pada perlakuan lama fermentasi 48 jam adalah $56 \mathrm{ml}$ dan $11.081 \%$; dan volume serta konsentrasi bioethanol pada perlakuan lama fermentasi 72 jam adalah $67 \mathrm{ml}$ dan $14.043 \%$.

Ethanol merupakan senyawa Hidrokarbon dengan gugus Hydroxyl (-OH) dengan 2 atom karbon $(C)$ dengan rumus kimia $\mathrm{C}_{2} \mathrm{H}_{5} \mathrm{OH}$. Secara umum Ethanol lebih dikenal sebagai Etil Alkohol berupa bahan kimia yang diproduksi dari bahan baku tanaman yang mengandung karbohidrat (pati). Bahan baku tersebut merupakan tanaman yang biasa ditanama oleh masyarakat ataupun tumbuh secara alami pada habitat tertentu. $S$. crassifolium merupakan jenis tumbuhan air yang tumbuh di laut dengan membentuk koloni yang besar serta mengapung pada permukaan air asin. Sargassum sendiri masuk ke dalam tumbuhan jenis alga coklat yang selain mengandung iodium yang tiggi, juga mengandung selulosa serta pati yang tinggi. Kandungan karbohidrat total S. crassifolium adalah 33,3\% yang merupakan komponen terbesar diantara yang lainnya. Tingginya kandungan karbohidrat pada sargassum, sehingga dapat dijadikan sebagai bahan baku dalam pembuatan bahan bakar yang ramah lingkungan, yang diistilahkan dengan bioethanol. Secara umum ethanol biasa digunakan sebagai bahan baku industri turunan alkohol, campuran untuk miras, bahan dasar industri farmasi, kosmetika dan kini sebagai campuran bahan bakar untuk kendaraan bermotor. Pembuatan bioethanol melalui proses fermentasi yang dibantu oleh mikroorganisme seperti S. cereviceae pada interval waktu tertentu dan derajat keasaman medium. Olehnya itu, penelitian ini menggunakan 3 
perlakuan (konsentrasi ragi, $\mathrm{pH}$, dan lama fermentasi) untuk melihat dampaknya terhadap produksi dan kadar bioethanol yang dihasilkan dari S. crassifolium.

\section{Pengaruh pH Medium Fermentasi dan Lama Fermentasi Terhadap Produksi Bioethanol (ml)}

Bioetanol $\left(\mathrm{C}_{2} \mathrm{H}_{5} \mathrm{OH}\right)$ merupakan salah satu biofuel yang hadir sebagai bahan bakar alternatif yang lebih ramah lingkungan dan sifatnya yang terbarukan. Merupakan bahan bakar alternatif yang diolah dari tumbuhan yang memiliki keunggulan karena mampu menurunkan emisi $\mathrm{CO}_{2}$ hingga $18 \%$, dibandingkan dengan emisi bahan bakar fosil seperti minyak tanah (Anonim, 2007a). Bioetanol dapat diproduksi dari berbagai bahan baku yang banyak terdapat di Indonesia, sehingga sangat potensial untuk diolah dan dikembangkan karena bahan bakunya sangat dikenal masyarakat. Tumbuhan yang potensial untuk menghasilkan bioetanol antara lain tanaman yang memiliki kadar karbohidrat tinggi, seperti tebu, nira, aren, sorgum, ubi kayu, jambu mete (limbah jambu mete), garut, batang pisang, ubi jalar, jagung, bonggol jagung, jerami, dan bagas (ampas tebu). Penggunaan $S$. crassifolium sebagai bahan baku dalam pembuatan bioethanol belum dilakukan, pada hal kandungan karbohidratnya paling tinggi bila dibandngkan dengan komposisi kimia lainnya. Menurut Tri Handayani, Sutarno, Ahmad Dwi Setyawan (2004) menyatakan bahwa kandungan karbohidrat dari S. crasifolium adalah $36,93 \%$ lebih besar bila dibandingkan dengan protein dan lemak yang masing-masing $5,19 \%$ dan 1,63\%. Hal yang sama dikemukakan oleh Fahri, M (2010) yang menyatakan bahwa secara umum $S$. crassifolium mempunyai kandungan nutrisi cukup lengkap. Secara kimia rumput laut terdiri dari air $(27,8 \%)$, protein $(5,4 \%)$, karbohidrat $(33,3 \%)$, lemak $(8,6 \%)$ serat kasar $(3 \%)$ dan abu $(22,25 \%)$. Selain karbohidrat, protein, lemak dan serat, rumput laut juga mengandung enzim, asam nukleat, asam amino, vitamin (A, B, C, D, E dan K) dan makro mineral seperti nitrogen, oksigen, kalsium dan selenium serta mikro mineral seperti zat besi, magnesium dan natrium. Kandungan asam amino, vitamin dan mineral rumput laut mencapai 10-20 kali lipat dibandingkan dengan tanaman darat. Bila dibandingkan antara kandungan protein, lemak, dan karbohidrat maka komponen karbohidrat lebih besar bila dibandingkan dengan keduanya, sehingga atas dasar tersebut maka S. crasifolium dapat dijadikan sebagai bahan baku pembuatan bioethanol

Dengan menggunakan perlakuan konsentrasi ragi, $\mathrm{pH}$ medium fermentasi, dan lama fermentasi diperoleh hasil bahwa ada pengaruh perlakuan terhadap produksi bioethanol dengan perlakuan yang terbaik adalah (konsetrasi ragi 3\%, pH 7, dan lama fermentasi 72 jam). Penggunaan ragi dalam penelitian berfungsi sebagai mikroorganisme yang melakukan fermentasi glukosa menjadi ethanol. Di dalam ragi terkandung $S$. cereviceae yang memiliki kemapuan besar dalam merombak gula menjadi ethanol. Menurut Oura (2009), menyatakan bahwa S. cereviceae dikenal sebagai baker's yeast yang memiliki kemampuan paling tinggi dalam memfermentasi gula menjadi ethanol pada kondisi anaerob fakultatif. Hal yang sama dikemukakan oleh Trianik Widyanigrum 
et al (2016) yang menyatakan bahwa penggunaan $S$. cereviceae dapat mempercepat periombakan glukosa menjadi ethanol, dan semakin tinggi konsetrasi S. cereviceae yang digunakan, maka produksi bioethanol semakin besar karena dipengaruhi oleh banyaknya sel yang melakukan proses perombakan glukosa menjadi ethanol. Selama nutrisi dalam medium tersedia, maka mikroorganisme yang bersangkutan akan terus melakukan perombakan dan akan berakhir seiring dengan menurunnya nutrisi di dalam medium.

Selain penggunaan ragi, perlakuan $\mathrm{pH}$ medium fermentasi akan memberikan pengaruh terhadap produksi bioethanol. $\mathrm{pH}$ merupakan kondisi asam-basa medium suatu mikroorganisme yang dapat mempengaruhi pertumbuhan (aktivitas pembelahan sel) dari mikroorganisme tertentu. Menurut Endro Saputro dan Tri Sumiyati (2016), menyatakan bahwa $\mathrm{pH}$ sangat berperan penting dalam pertumbuhan mikroorganisme fermentasi. $\mathrm{pH}$ berkenaan dengan derajat keasaman medium yang akan menentukan aktivitas mikroorganisme selain ketersediaan nutrisi. $\mathrm{pH}$ yang paling baik dalam kombinasi perlakuan adalah 8 , hal ini bertentangan dengan pendapat Oura (2009) yang menyatakan bahwa $\mathrm{pH}$ yang paling baik untuk pertumbuhan $S$. cereviceae berkisar antara 4,0 - 4,5. Perbedaan $\mathrm{pH}$ yang ditemukan oleh peneliti dengan penelitian sebelumnya diduga karena penelitian sebelumnya tidak menggunakan variasi perlakuan dengan factor lain, peneliti sebelumnya hanya menggunakan satu factor variabel bebas yaitu $\mathrm{pH}$, sedangkan peneliti menggunakan 3 faktor yang dikombinasikan yaitu konsetrasi ragi, $\mathrm{pH}$ medium, dan lama fermentasi. Adanya perbedaan perlakuan ini, diduga memberikan dampak terhadap kebutuhan nilai $\mathrm{pH}$ yang dibutuhkna oleh $S$. cereviceae yang terdapat di dalam ragi.

Selain faktor konsetrasi ragi dan $\mathrm{pH}$ medium fermentasi, lama fermentasi merupakan salah satu bagian dari kombinasi perlakuan yang memberikan pengaruh terhadap produksi bioethanol yang dihasilkan dengan menggunakan S. crasifolium sebagai bahan baku. Lama fermentasi yang memberikan hasil yang paling baik adalah 72 jam, artinya bahwa fase logaritmik berlangsung pada waktu tersebut. Fase logaritmik adalah fase pertumbuhan tercepat yang dialami oleh mikroorganisme karena ketersediaan nutrisi yang lebih banyak dibandingkan dengan keberadaan sel mikroba. Banyaknya nutrisi mengakibatkan ketersediaan energi mikroba dalam jumlah yang besar untuk merombak glukosa menjadi ethanol. Pendapat ini sejalan dengan hasil temuan dari Endro Saputro dan Tri Sumiyati (2016) yang menyatakan bahwa produksi ethanol dipengaruhi oleh lama fermentasi, dimana lama fermentasi berkenaan dengan waktu logaritmik yang dimiliki oleh mikroba untuk berada dalam jumlah yang banyak dalam merombak glukosa menjadi ethanol. Jika terlalu lama waktu fermentasi, maka produksi ethanol dapat berkurang karena terjadinya kematian sel mikroba yang disebabkan oleh kekurangan nutrisi atau karena keracunan $\mathrm{CO}_{2}$ yang merupakan produk samping dari proses fermentasi anaerobik.

Salah satu cara untuk mendapatkan bioethanol adalah melalui proses fermentasi secara anaeribik pada bahan yang mengandung amilum (Sugili Putra, 2006). Sargassum 
berupa kulit pisang, biji durian, dan singkong. Hasil penelitian yang ditemukan bertentangan dengan penelitian sebelumnya karena $\mathrm{pH}$ yang menunjukkan hasil terbaik dalam penelitian ini adalah $\mathrm{pH}$ dalam kondisi netral. Hal ini diduga karena perbedaan bahan baku yang digunakan yang memerlukan nilai $\mathrm{pH}$ yang lebih tinggi bila dbandingkan dengan bahan organik lainnya.

Perombakan glukosa menjadi ethanol juga dipengaruhi oleh lama fermentasi, karena terkait dengan interval waktu yang dibutruhkan oleh mikroba untuk merombak substrat menjadi produk. Mikroba memiliki fase pertumbuhan yang berkenaan dengan waktu pertumbuhan. Mikroba akan bertambah dalam jumlah yang tinggi pada fase logaritmik, sehingga kemampuannya dalam menggunakan nutrisi akan semakin besar dan hal ini akan berdampak terhadap produk yang dihasilkan. Hasil penelitian yang dilakukan oleh Fifi Nurfiana, dkk (2009) dan Diah Rsetu dan Anastasia rafika (2013) menunjukkan bahwa interval waktu 24 jam-72 jam memberikan hasil tertinggi terkait kadar ethanol berbahan baku biji durian dan kulit pisang kepo. Hasil penelitian tersebut sejalan dengan temua peneliti yang menemukan bahwa waktu 72 jam memberikan hasil baik terkait kadar ethanol berbahan dasar S. crasifolium.

\section{KESIMPULAN}

1. Ada pengaruh variasi $\mathrm{pH}$ terhadap peningkatan volume $(\mathrm{ml})$ bioethanol dari $S$. crasifolium dengan $\mathrm{pH}$ yang terbaik adalah 7

2. Ada pengaruh lama fermentasi terhadap peningkatan volume (ml) bioethanol dari $S$. crasifolium dengan lama fermentasi terbaik adalah 72 jam

\section{SARAN}

Perlu dilakukan penelitian lanjutan dengan melakukan kombinasi perlakuan antara konsetrasi ragi dengan $\mathrm{pH}$ medium, konsentrasi ragi dengan lama fermentasi, dan konsentrasi ragi dengan $\mathrm{pH}$ serta lama fermentasi. Selain itu, perlu adanya penambahan variabel lain yaitu pengukuran kadar gula tereduksi setelah proses deliginasi secara kimiawi atau penggunaan enzim yang berasal dari mikroba tertentu.

\section{DAFTAR PUSTAKA}

Ariyani Endang, dkk. 2013. Produksi Bioetanol Dari Jerami Padi (Oryza sativa L). Journal of Chemical Science, 2 (2).

Atmadja, W.S., A. Kadi, Sulistidjo, dan Rachmaniar. 1996. Pengenalan Jenis-jenis Rumput Laut. Jakarta: Puslitbang Oseanologi LIPI.

Azizah N, dkk. 2012. Pengaruh Lama Fermentasi Terhadap Kadar Alkohol, pH, dan Produksi Gas pada Proses Fermentasi Bioetanol Dari Whey dengan Substitusi Kulit Nanas, Jurnal Aplikasi Teknologi Pangan, Vol. 1, No. 2. 
Bold, H.C., Wayne, M.J. 1985. Introduction to the Algae. Second Edition. New Jersey: Prentice Hal, Inc Englewood Cliffs,

Castro, R, dkk. 2004. Water-soluble Seaweed Extract Modulate the Pantoeaa Agglomerans Lipopolysaccharide (LPS) Fish Shelfish Immunol. 10: 555-558.

Fitriana Lili. 2009. Analisis Bioetanol Hasil Fermentasi Dari Pati Sagu (Metroylon sago) Asal Papua. Skripsi Jurusan Kimia FMIPA Universitas Negeri Papua.

Jasminandar, Y. 2009. Penggunaan Ekstrak (Gracilaria verrucosa) Untuk Meningkatkan Sistem Ketahanan Udang vaname (Litopenaeus vannamei). Tesis Pasca Sarjana Institut Pertanian Bogor..

Khairani, Rini. 2007. Tanaman Jagung Sebagai Bahan Bio-fuel http://www.Macklintmip unpad. net/ Biofuel/ Jagung/ Pati.pdf. diakses tanggal 14 Agustus 2016

Khaidir, Setyaningsih, Haerudin. 2012. Dehidrasi bioetanol menggunakan zeolit alam termodifikasi. Jurnal Teknologi Industri Pertanian. Institut Pertanian Bogor.

Mangunwidjaja, D dan Sailah, I. 2005. Pengantar Teknologi Pertanian. Depok: Penebar Swadaya.

Nurfiana F. dkk. 2009. Pembuatan Bioetanol Dari Biji Durian Sebagai Sumber Energi Alternatif. Teknokimia Nuklir. Yogyakarta: Sekolah Tinggi Teknologi Nuklir Badan Tenaga Nuklir Nasional (STTN-BATAN).

Handayani, W. 1999. Ekstraksi dan Karakterisasi Alginat dari Rumput Laut Sargassum spp. (Laporan Penelitian). Yogyakarta: Fakultas Teknologi Pertanian UGM.

Hidayat, A. 1994. Budidaya Rumput Laut. Usaha Nasional, Surabaya

Rahmawati Ani, "Pemanfaatan Limbah Kulit Ubi Kayu (Manihot uttilisima Pohl) dan Kulit Nanas (Anana Comosus L) Pada Produksi Bioetanol Menggunakan Aspergilus wenti", Jurnal Pembuatan Bioetanol (online), diakses pada 16 Agustus 2016.

Richana Nur. 2011. Bioetanol; Bahan Baku Teknologi Produksi Dan Pengendalian Mutu. Bandung: Nuansa Cendikia.

Pujiani dkk. 2014. Biokeonversi Selulosa Dari Tongkol Jagung Menjadi Bioetanol. Jurnal Alkohol (online). diakses pada 1 September 2016

Pujianingsih, I. r. 2005. Teknologi Fermentasi Dan Peningkatan Kualitas Pakan. Fakultas Peternakan. Semarang: Universitas Diponegoro.

Pusdatin. 2010. Buku Pegangan Statistik Ekonomi Energi Indonesia DESDM 2010. http://www.esdm.go.id/publikasi/indone sia-energy-outlook/ringkasaneksekutif/doc_download/1255- ringkasan-eksekutif-indonesia-energy- outlook2010.html. diakeses tanggal 1 September 2016

Santi S. Sinta. 2008. Pembuatan alkohol dengan Proses Fermentasi Buah Jambu Mete Oleh Khamir Sacharomyces cereviceae. Jurnal Penelitian Ilmu Teknik, Vol 8, No 2, (Desember 2008). 
Saputra R D, dkk. 2012. Kajian Rumput Laut Sargassum duplicatum J. G. Agardh sebagai Penghasil Bioetanol dengan Proses Hidrolisis Asam dan Fermentas. Journal Of Marine Research. Volume 1, Nomor 2, Tahun 2012, Halaman 145-151

Sari N R, dkk. 2014. Kondisi Optimum Produksi Bioetanol Dari Rumput Laut Coklat (Sargassum duplicatum) Menggunakan Trichoderma viride Dan Pichia angophorae. Balai Besar Penelitian Dan Pengembangan Pengolahan Produk Dan Bioteknologi Kelautan Dan Perikanan. Institut Pertanian Bogor. JPB Perikanan Vol.9 Desember

Sugiono. 2013. Statistik untuk Penelitian. Bandung: Alfabeta.

Suprihatin. 2010. Teknik Fermentasi. Surabaya: UNESA University Press.

Rahmawati Ani. 2013. Pemanfaatan Limbah Kulit Ubi Kayu (Manihot uttilisima Pohl) dan Kulit Nanas (Anana Comosus L) Pada Produksi Bioetanol

Riadi Lieke. 2013. Teknologi Fermentasi Edisi 2. Yogyakarta: Graham Ilmu.

Yowono Triwibowo. 2005. Biologi Molekuler. Jakarta: Erlangga

Zen. 1988. Energi, Sumberdaya, Lingkungan Hidup dalam Pembangunan Berkesinambungan. Jakarta: Penerbit Dian Rakyat. 